\title{
Group work management in the classroom
}

\author{
Karin Forslund Frykedal and Eva Hammar Chiriac
}

\section{Linköping University Post Print}

N.B.: When citing this work, cite the original article.

This is an electronic version of an article published in:

Karin Forslund Frykedal and Eva Hammar Chiriac, Group work management in the classroom, 2012, Scandinavian Journal of Educational Research, (56), 5, 1-13.

Scandinavian Journal of Educational Research is available online at informaworld ${ }^{\mathrm{TM}}$ :

http://dx.doi.org/10.1080/00313831.2012.7225098

Copyright: Taylor \& Francis (Routledge) http://www.routledge.com/

Postprint available at: Linköping University Electronic Press http://urn.kb.se/resolve?urn=urn:nbn:se:liu:diva-84617 


\title{
Group Work Management in the Classroom
}

\author{
Karin Forslund Frykedal ${ }^{1}$ and Eva Hammar Chiriac \\ Department of Behavioural Sciences and Learning, University of Linkoping, Linkoping, \\ Sweden
}

This study aims to provide a better understanding of teachers' managing roles when using group work in the classroom. Building on Granström's (2007) two concepts of leadership and teachership, a more specific aim is to investigate teachers' managing roles when using group work and how teachers' presumptions affect the way in which they manage the pedagogical mode. The results show that teachers' managing roles influence teachers' willingness to use group work. Teachers may be unwilling to use group work based on their presumption that it teaches students only collaboration abilities and not subject knowledge. This may be a supplemental yet significant explanation as to why group work continues to decrease in classrooms.

Keywords: teacher presumptions, group work, leadership, teachership

\section{Introduction}

There are three basic means of organising classroom activity-whole-class lessons, group work or individual work (Granström, 1998; 2006). Each activity type offers its own advantages and disadvantages, as well as possessing unique characteristics which might either promote or inhibit learning processes in the classroom. The choices teachers make with regard to the setting for students' learning may produce different challenges, but can also result in enjoyment for both teachers and students. Rather than attempting to problematise the professional use of various methods in the classroom, this study will focus on group work as one applicable pedagogical method for learning in compulsory education involving students ages 11-16. Even though group work is not the only available method for learning, this article chooses to bring attention to the managing roles of teachers when using this particular pedagogical mode in their work. (For a more in-depth discussion of group work as a pedagogical practice, see Granström, 2006; 2007; Hammar Chiriac, 2010; Hammar Chiriac \& Forslund Frykedal, 2011.)

\footnotetext{
${ }^{1}$ Corresponding author. Email: karin.forslund.frykedal@liu.se
} 


\section{Group work}

Group work is a teaching strategy that promotes academic achievement and socialisation (Baines, Blatchford \& Chowne, 2007; Gillies, 2003; Johnson \& Johnson, 2004; Oliveira \& Sadler, 2008; Summers, Beretvas, Svinicki \& Gorin, 2005). By interacting with others students learn to inquire, share ideas, clarify differences and construct new understandings. They thereby learn to use language to explain issues, which in turn helps them construct new ways of thinking (Webb \& Mastergeorge, 2003). According to Gillies (2003), students are also more motivated to achieve when working in groups as opposed to working individually. This picture is nevertheless appositional to contemporary research findings, which reveals that time spent learning collectively in the classroom is decreasing in favour of time spent learning individually (Baines, Blatchford \& Kutnick, 2003; Ekholm, 1996; Galton, Hargreaves, Comber, Wall \& Pell, 1999; Granström, 2006). The tendency to employ collaborative group work in the classroom only sparingly seems to hold true across many countries, and certainly is the case in Sweden (Granström, 2006; Säljö, Jakobsson, Lilja, Mäkitalo, Åberg, 2011; The Swedish National Agency for Education, 2009; Williams \& Sheridan, 2010), the UK (Sanford \& Evertson, 1982), US (Schmuck \& Schmuck, 1992) and Australia (Gillies \& Boyle, 2010), which implies that a number of teachers are reluctant to use group work as a pedagogical tool in the classroom (Gillies \& Boyle, 2010).

One oft-stated reason for the decreased use of this pedagogical mode is that group work can give rise to classroom activities and processes among students that may be difficult for the teacher to control (Gillies \& Boyle, 2010; Granström, 2006). A second possible explanation may be that teachers lack knowledge of how to manage group work and how to organise it in a productive manner (Gillies \& Boyle, 2010; Lotan, 2006; 2008). Several authors stress the importance of teachers taking the opportunity to practice group work as a classroom activity (Gillies \& Boyle, 2010; Johnson \& Johnson, 2003). Previous negative experiences involving group work in the classroom may be a final conceivable explanation (Gillies \& Boyle, 2010; Granström, 2006). Two potentially fruitful ways of reducing teachers' unwillingness to use group work to facilitate learning may be 1) to learn more about group processes and how to use them in a positive way, and 2) to learn how to manage group situations in ways that acknowledge the group's potential for learning and development. In this study, we direct our interest towards the managing roles of teachers in their use of group work in the classroom. 


\begin{abstract}
Aim
Bearing in mind these potential explanations for the decreased use of group work, our ambition here is to provide a better understanding and enhanced knowledge of teachers' managing roles when using group work in the classroom. A more specific aim is to investigate both teachers' managing roles when using group work and how teachers' presumptions affect their way of managing the teaching mode, with the support of Granström's (2007) concepts of leadership and teachership.
\end{abstract}

\title{
Classroom management
}

Important prerequisites for productive or unproductive group work, in students' opinions, are closely connected to classroom management (Granström, 2006; 2007; Hammar Chiriac \& Granström, 2009; 2012). Hindrances to, or prerequisites of, group work are to some extent factors that teachers have to deal with when planning and implementing group work in their classrooms. Some studies indicate that teachers often choose a mode of working in the classroom based on their own preferences and working situation (Gillies \& Boyle, 2010; Granström, 2006; Lumpe \& Hanely, 1998). These pedagogical modes are not always grounded in students' needs or evidence-based knowledge. One way for teachers to avoid the difficult group processes which may come up in group work is to employ alternative modes, such as whole-class lessons or individual work. On the other hand, such lessons might deprive students of a powerful means of learning from each other and, in doing so, gaining experience which will be valuable in future collaborative work in real-life situations. Many teachers argue that they have tried and abandoned group work as a mode of working in the classroom because of previous negative experiences, or simply because, in their own words, "It doesn't work." According to these teachers, students fail to take responsibility for learning, or do not learn enough when working in groups (Gillies \& Boyle, 2010; Granström, 2007; Hammar Chiriac \& Forslund Frykedal, 2011).

Some teachers are unable or unwilling to delegate responsibility and allow students to solve problems for themselves. They want to control the students, and therefore prefer working with a small number of groups, preferably with an adult supervising each group (Cohen, 1994; Gillies \& Boyle, 2010). Cohen (1994) has nevertheless shown that the greatest learning gains were obtained in classrooms where teachers successfully delegated responsibility. When teachers control the students and refuse to assign them any accountability, it is not necessary for the students to assume any responsibility for their own learning (Webb, Nemer \& Ing, 2006). It is not until the teachers relinquish some measure of 
control, and thereby hand over the responsibility of engaging in the task to students, that students will take charge of their own learning processes. When teachers successfully delegate responsibility to the group, then students start to collaborate and serve as resources for each other (Lotan, 2008).

\section{Leadership and Teachership}

The teachers' role in the classroom is significant and may be schematised in various ways in connection with classroom management and when implementing group work (Gillies, 2008; Gillies, Ashman \& Terwel, 2008; Hammar Chiriac \& Granström, 2009; 2012; Lotan, 2006; Webb, 2008). Irrespective of the pedagogical mode to be implemented, the teacher always retains ultimate responsibility for all actions and processes occurring in the classroom. Based on empirical research, Granstöm (1998; 2006; 2007) proposes one way to interpret and describe teachers' ambiguous management roles in the classroom. Granström (2007) points out that, for teachers in the classroom, one task involves supervising a group of students in their effort to acquire knowledge, while secondly being expected to be completely responsible for all activities and processes occurring in the classroom. This presupposes that teachers are able to efficiently manage the two important roles associated with classroom management, namely leadership and teachership. Leadership and teachership may be seen as two different, complementary aspects of a teacher's managing role in the classroom. The concepts and requirements are defined as follows:

Leadership in the classroom:

- knowledge about classroom interaction and group processes

- ability to handle classroom interaction and group processes

Teachership in the classroom:

- $\quad$ knowledge of subjects

- ability to convey knowledge or proficiencies (Granström, 2007, p. 17)

The two roles complement each other and are both necessary, but neither is sufficient independently. A professional teacher practising his or her profession requires capabilities which draw upon both leadership and teachership. As elucidated in the definitions above, leadership in the classroom includes teachers' knowledge of interactive and group processes, along with the ability to manage these processes. It consists, for instance, of the teacher's 
ability to arrange and accomplish different modes of classroom activities, including group work. In addition, a skillful leader has the ability to lead and activate the students, irrespective of the type of classroom practice. This teacher role is significant for all social courses of events in the classroom, and for the relationship between all involved individuals. Teachership in the classroom, on the other hand, draws upon knowledge of how to manage theoretical proficiencies in the educational situation, as well as the ability to convey knowledge and create learning opportunities for students. Teachership thus includes both a teacher's subject knowledge and knowledge of different pedagogical modes available for use in the classroom. A skillful teacher is highly skilled academically, and has a great ability to convey knowledge to students. Teachership is essential for both the academic achievement of students as well as the development of collaborative skills among students. The definitions of these concepts are neither conclusive nor comprehensive, but they provide a sense of the features connected to the concepts and offer the opportunity to investigate classroom management and teacher roles (Granström, 2007). There may be teachers who practise good or bad teachership as well as good or bad leadership in the classroom. Based on these starting points, a four-field figure can be constructed (see Figure 1).

Teachership

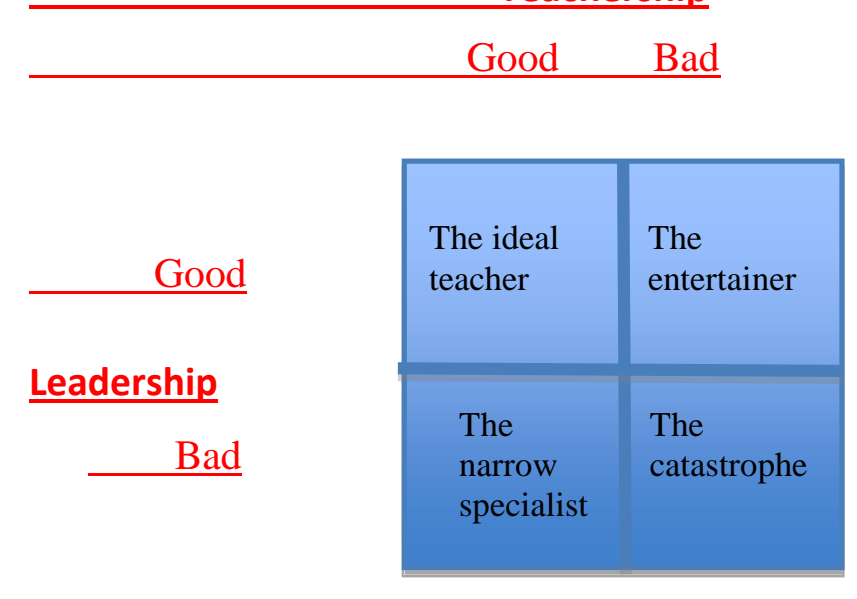

Figure 1. Four different ways of classroom management (based on Granström, 2007, p. 18).

[nsert figure 1 about here] 
Cell 1. The ideal teacher. A knowledgeable teacher practises their role as a professional teacher. Furthermore, the ideal teacher is eminently capable of organising and leading in the classroom.

Cell 2. The entertainer. This is a teacher who is more than capable of organising and activating students in the classroom, but who lacks comprehensive knowledge of the subject matter. This teacher might skilfully keep the students busy with different activities, but he or she is not very interested in the subject in question.

Cell 3. The narrow specialist. This is a knowledgeable teacher who principally teaches while standing at their desk. He or she is not skilled in organising different classroom activities, but the expert teacher is highly skilled in the subject and has a great ability to convey knowledge or proficiencies to the students.

Cell 4. The catastrophe. This is a teacher incapable of maintaining order in the classroom and lacking the knowledge or ability to teach the subject in question. The students feel deserted and have to handle the classroom situation in the best possible way they can.

With the support of these two concepts, Granström (2007) has named four variants of teaching practices detectable in teachers' managing roles in the classroom. These evidencebased descriptions encompass teachers' management on a general level and do not focus on any specific classroom activity. In this text, our intention is to elaborate on the concepts while focusing on group work as a pedagogical mode.

\section{Presumptions}

In a previous article (Hammar Chiriac \& Forslund Frykedal, 2011) we have shown that the concepts of leadership and teachership introduced by Granström (2007) could be beneficial to but are not sufficient for a profound understanding of group work management in the classroom. By employing symbolic interactionism (SI) as a complementary theoretical perspective (Blumer, 1969; Charon, 2006) it was possible to discover how teachers' takenfor-granted unreflective ideas affect their acts. In other words, teachers' unreflective ideasas opposed to reflective ideas - are ideas not considered by or elucidated to themselves or others. The use of SI enables us to expose the social processes teachers participate in, which also exert influence on them if and when they are to use group work as a pedagogical mode. From a symbolic interactionary point of view, surroundings are perceived as social interpretations of meaning through a definition of the situation. Teachers' considerations and 
actions are ruled by their interpretations of the definition of the situation. These interpretations are, in turn, influenced by the individual's history and thoughts about the future. Based on SI, the concept of presumption has allowed us to reveal teachers' taken-forgranted unreflective ideas of how to arrange and implement group work which, in turn, affects their management of group work in the classroom. Presumptions include (a) unreflective ideas about the teacher's own subject knowledge and their ability to convey this knowledge through group work, and (b) unreflective ideas about the teacher's own knowledge about classroom interaction and group processes and their ability to organise and handle the interaction and group processes (compare with Figure 1).

Presumption conceptually resembles previous findings from studies investigating teachers' beliefs and cooperative grouping in science education (Lumpe \& Haney, 1998). Dissimilarities do exist, however, foremost being whether or not the act is reflective. Researchers employing the Theory of Planned Behaviour assessed the influence of teachers' salient beliefs as well as their planned behaviour to employ cooperative learning in the classroom. Even though certain differences exist between the concept of salient beliefs (Lumpe \& Haney, 1998) and our use of presumption, the results point in the same direction: Teachers' presumptions or beliefs are important factors affecting teachers' willingness to employ group work as a classroom activity. The concept of presumption has increased the knowledge and understanding of the teachers' modes of proceeding as well as their reluctance to use group work.

\section{Method}

The data this text draws upon originates from an extensive study intended to develop knowledge of teachers' experiences with group work as a pedagogical mode in educational settings (Hammar Chiriac \& Forslund Frykedal, 2011). Data collection was accomplished by means of three focus groups with a total of 11 teachers who educated students ages 11-16 years. The informants were drawn from three schools with varying demographic characteristics, from different counties in southern Sweden. The teachers in each focus group belonged to the same working team or were from the same school. Each focus group lasted an average of 78 minutes, yielding a total data corpus of nearly four hours. The three focus groups were carried out over a two-month timeframe. Audio recordings were made of each focus group discussion, and these were transcribed verbatim. 


\section{Analysis 1}

A grounded theory inspired analysis was performed using the verbatim transcriptions (Charmaz, 2006; Glaser \& Strauss, 1967; Glaser, 1978). In this study, the analytical process began with several independent perusals of the data, while the researchers simultaneously analysed the text by carrying out initial coding (Charmaz, 2006). During the initial coding stage several codes were readily apparent; these, in turn, were elaborated and allocated to five discrete categories: (a) compose groups; (b) keep the students busy; (c) keep the students as a group; (d) ability training; and (e) teaching group work. Focused coding using theoretical sampling (Charmaz, 2007) was carried out to refine the categories, and the dimensions defining each category were made explicit. This was done by recoding the empirical data according to the five categories thus defined. At this point, the concepts of leadership and teachership became sensitising concepts (Blumer, 1969) for the continuing process, and were beneficial in the continuing analysis, as they helped to elucidate the teachers' mode of proceeding when using group work in their lessons.

From this point, the analysis divided the results into two distinctly different parts, with the first pertaining to the two concepts laid out above and the second, the grounded theory inspired analysis, having been constructed through constant comparative analysis. The grounded theory inspired analysis depicted the concept of presumption as concerning teachers' taken-for-granted unreflective ideas regarding the use of group work. Teachers' presumptions which increase the knowledge and understanding of which aspects affect teachers' group work management, as well as their reluctance to use the pedagogical mode, centred on the following aspects: (a) students would rather work individually than in a group, (b) time and space constraints hinder group work, (c) absence of a common description of group work constitutes a hindrance and a precondition to the use of group work, and (d) students mostly learn collaboration abilities when working in groups.

\section{Analysis 2}

The results of the previous empirical study (Hammar Chiriac \& Forslund Frykedal, 2011) serve as a point of departure for the subsequent development of teachers' managing roles. Previous analyses have been inspired by grounded theory, with results emerging from the empirical data. A more deductive approach was applied in this second analysis (Bryman, 2012). Through deductive analyses - those being the theoretical concepts used to guide the analysis - we were able to infer that Granström's (2007) four types of classroom management were beneficial to, but not sufficient for, a more complete understanding of teachers' 
management of group work. From the deductive analyses, it became evident that teachers' presumptions with regard to group work played an important role. Additional analyses revealed the interplay between teachers' presumptions, leadership and teachership, and the four managing roles. A pattern representing teachers' possible managing roles when using group work as a mode was constructed. The pattern displayed the relation between the presumptions, the concepts of leadership and teachership, and the four different types of group work management (see Table 1).

Both analysis one and analysis two were carried out in several steps by the two researchers. The researchers carried out these procedures independently. The analyses were compared, and the results proved to coincide with respect to content and meaning, if not in wording. After thorough discussion, the researchers agreed upon the labels used in this presentation.

\section{Ethics of the study}

The British Psychology Society's (BPS) four ethical principles of respect, competence, responsibility and integrity have been applied throughout this study (BPS, 2006). In agreement with these ethical principles, concern for participants' interests has been emphasised (APA, 2002; Barrett, 2007; BPS, 2004). The quality of this qualitative research has been assured and measured based on validity and reliability (Bryman, 2012).

\section{Different teacher management roles regarding the mode of group work}

Adopting the concepts of leadership and teachership as a point of departure, Granström (2007) has identified four different supervisory roles for teachers: the ideal teacher, the entertainer, the narrow specialist and the catastrophe. Granström has not explicitly connected these four teacher roles to the pedagogical mode of group work, which is a primary contribution made by this article. We also contribute to the theoretical discussion by introducing the concept of presumption. By studying teachers' presumptions we provide additional explanations for teachers' reluctance to use group work in the classroom. Presumption allows us to gauge the relative influence of different roles, and how teachers' presumptions affect their way of managing when using group work as mode. Table 1, whose content is derived from our previously published empirical data (Hammar Chiriac \& Forslund Frykedal, 2011), shows the developed modes of teacher roles when using group work as a mode. 
ID SJER-2011-0206

$\underline{\text { Table } 1}$

Teachers' roles and group work

\begin{tabular}{|c|c|c|c|c|}
\hline $\begin{array}{l}\text { Teacher's } \\
\text { management of } \\
\text { group work }\end{array}$ & The ideal teacher & The entertainer & $\begin{array}{l}\text { The narrow } \\
\text { specialist }\end{array}$ & The catastrophe \\
\hline Presumption & $\begin{array}{l}\text { Group work may be } \\
\text { used to convey both } \\
\text { subject knowledge and } \\
\text { collaboration abilities } \\
\text { Knows how to organise } \\
\underline{\text { and manage group work }}\end{array}$ & $\begin{array}{l}\text { Organises and keeps } \\
\text { the students in } \\
\text { groups through the } \\
\text { assignment }\end{array}$ & $\begin{array}{l}\text { Avoids using group } \\
\text { work because the } \\
\text { students do not } \\
\text { learn the subject } \\
\text { through group work }\end{array}$ & $\begin{array}{l}\text { Does not use group } \\
\text { work and gives in } \\
\text { to the students' } \\
\text { demand for } \\
\text { individual work }\end{array}$ \\
\hline Leadership & $\begin{array}{l}\frac{\text { Knowledge of and }}{\text { ability to handle group }} \\
\frac{\text { work interactions and }}{\text { processes }}\end{array}$ & $\begin{array}{l}\text { Knowledge of and } \\
\text { ability to handle } \\
\text { group work } \\
\text { interactions and } \\
\text { processes }\end{array}$ & $\begin{array}{l}\text { Lack of knowledge } \\
\text { and ability to } \\
\text { handle group work } \\
\text { interactions and } \\
\underline{\text { processes }}\end{array}$ & $\begin{array}{l}\frac{\text { Lack of knowledge }}{\text { and ability to }} \\
\underline{\text { handle group work }} \\
\text { interactions and } \\
\text { processes }\end{array}$ \\
\hline & $\begin{array}{l}\text { Manages group work as } \\
\text { a method }\end{array}$ & $\begin{array}{l}\text { Manages group } \\
\underline{\text { work as a method }}\end{array}$ & $\frac{\text { Unable to organise }}{\text { group work }}$ & $\frac{\text { Unable to organise }}{\text { group work }}$ \\
\hline \multirow[t]{2}{*}{ Teachership } & $\begin{array}{l}\text { Knowledge of the } \\
\text { subject and ability to } \\
\text { convey knowledge or } \\
\text { proficiencies }\end{array}$ & $\begin{array}{l}\text { Insufficient } \\
\underline{\text { knowledge base }}\end{array}$ & $\begin{array}{l}\text { Knowledge of the } \\
\text { subject and ability } \\
\text { to convey } \\
\text { knowledge or } \\
\text { proficiencies }\end{array}$ & $\begin{array}{l}\text { Insufficient } \\
\underline{\text { knowledge base }}\end{array}$ \\
\hline & $\begin{array}{l}\text { Manages the core } \\
\text { content of the subject }\end{array}$ & & $\begin{array}{l}\text { Manages the core } \\
\text { content of the } \\
\underline{\text { subject }}\end{array}$ & \\
\hline
\end{tabular}

[Insert Table 1 about here]

The four managing roles of group work are situated archetypes constructed from the empirical data, and are difficult to identify in reality. From the table, it is easy to grasp that all four roles are influenced by teachers' presumptions concerning their management of group work as a classroom activity. The teachers' presumptions may facilitate or hamper the teachers' use of group work as a pedagogical mode.

As displayed, the ideal teacher has knowledge of and an ability to handle group work interactions and processes, is capable of managing the subject content and can handle any potential hindrances to group work. Additionally, the ideal teacher agrees that group work as a teaching strategy may promote academic achievement while simultaneously helping 
students to develop collaboration abilities. Our study thus shows that the ideal teacher's presumptions facilitate both leadership and teachership, and thereby increase the likelihood that they will use group work in the classroom.

Congruently, the entertainer has knowledge of and the ability to handle group work interactions and processes; however, he or she lacks a sufficient knowledge base in the relevant topic. The entertainer remains focused on keeping the students engaged during group work. The entertainer's presumptions may lead him or her to employ leadership skills if using group work, but might hamper the performance of their teachership, as well.

The third managing role, the narrow specialist, presents the opposite construction. The narrow specialist is an expert in the subject content, but avoids group work because of poorly developed leadership skills. Their presumption that students do not learn subject knowledge through group work influences the narrow specialist's determination as to whether or not to use group work, and can thus be seen to hamper the exercising of leadership when using group work, while promoting or positively influencing their teachership.

The last role, the catastrophe, relates a situation in which the teacher is unable to organise group work and has an insufficient knowledge base. Together, these characteristics lead to the total inability to support the group work mode. Our study shows that the teacher's presumptions hamper the exercising of both leadership and teachership. As a result, they will opt to give in to students' demands for individual work.

\section{Discussion}

In order to provide specific explanations for the decreased use of group work, this study has sought an increased understanding of teachers' managing roles when using group work in the classroom. We have also offered an understanding of how teachers' presumptions affect their way of managing the pedagogical mode of group work.

The results of this study show that it is possible, with the support of teachers' presumptions and Granström's (2007) concepts of leadership and teachership, to manifest archetypes of different managing roles teachers can use when educating by means of group work. These results demonstrate the importance of managing both leadership and teachership, in order to be able to act as a professional teacher in the classroom. The empirical data consequently elucidates the fact that knowledge and ability with regard to only one area is insufficient to facilitate the type of well-functioning group work that supports the development of both subject knowledge and collaboration abilities. In instances in which 
teachers attach negative connotations to the use of group work as a pedagogical tool they are more likely to consider the mode as less useful. This holds true regardless of whether the teacher's negative impression is derived from past personal experience. Rather than employing what they see as a low-functioning pedagogical mode, the teacher will refrain from using group work at all. This finding has been verified by a vast body of empirical research (Granström, 2006; Gillies \& Boyle, 2010; Lotan, 2006, 2008; Säljö et. al, 2011; The Swedish National Agency for Education, 2009; Williams \& Sheridan, 2010). Conversely, if teachers consider themselves to be able to manage the mode and possess experiences of its advantages, the probability of using group work increases. This result is in line with earlier research demonstrating that teachers often choose a pedagogical mode based on their own preferences and working situations, rather than one that is necessarily grounded in students' needs or evidence-based knowledge (Gillies \& Boyle, 2010; Granström, 2006; Lumpe \& Hanely, 1998; Säljö et. al, 2011; The Swedish National Agency for Education, 2009; Williams \& Sheridan, 2010). As shown in Table 1, all roles include knowledge and abilities associated with both leadership and teachership, but the modes eventually chosen are influenced by teachers' presumptions, as well. Our results thus indicate that teachers' presumptions may facilitate or hamper their interest in employing group work as a pedagogical mode (Hammar Chiriac \& Forslund Frykedal, 2011).

The results also confirm that classroom management is an important prerequisite for group work (Granström, 2006; 2007; Hammar Chririac \& Granström, 2009; 2012). To facilitate smoothly functioning group work, a teacher must possess leadership, teachership and presumptions about group work that facilitate its use. One especially significant presumption has to do with whether the teacher presumes group work will promote both academic achievement and socialisation (Baines et al., 2007; Gillies, 2003; Johnson \& Johnson, 2004; Oliveira \& Sadler, 2008; Summers et al., 2005). For instance, if the teacher presumes students only learn collaboration abilities and not subject knowledge, as shown in Hammar Chiriac and Forslund Frykedal (2011), then the teachers' willingness to use group work as a pedagogical tool will decrease. Teachers' enthusiasm for the use of group work will therefore depend on which managing role they assume.

The ideal teacher manages the core content of the subject and group work as a method; his or hers presumptions acknowledge that group work may be used as a means of facilitating both subject learning and collaborative abilities. All aspects of this role consequently foster the teachers' willingness to use group work. The entertainer is an 
effective organiser, but has an insufficient knowledge base. The entertainer's presumptions stimulate the use of group work when collaborative abilities are emphasised, but hinder its use when subject knowledge is the focus. The narrow specialist exemplifies the opposite, being a subject expert with poorly developed organisational abilities. The narrow specialist's presumptions emphasise that students do not learn subject knowledge when using the mode and, therefore, they will be resistant to the use of group work. Finally, the catastrophe has both insufficient leadership and teachership abilities, both of which inhibit group work. The catastrophe avoids group work because their presumptions inform them that students prefer to work individually.

Previous negative experiences with group work, or the hope of avoiding difficult group processes or dynamics, are other potential explanations as to why teachers may opt for other pedagogical modes. This study presents a significant supplementary explanation as to why group work has become less common in the classroom, suggesting that teachers' presumptions may increase or decrease the likelihood that they choose group work; hence, presumptions can be seen to either facilitate or hamper the use of group work. Teachers' presumptions about the importance of controlling students' activities could also prevent them from using group work, as can their presumptions that students' would rather work individually than collaboratively. Both of these presumptions could restrict the opportunities for students to collaborate with and to serve as resources for one another (Lotan, 2006; 2008). Empirical research has suggested that students who work in groups tend to achieve better learning outcomes (Baines et al., 2007; Bennet, Lubben \& Campell, 2004; Gillies, 2003; Oliveira \& Sadler, 2008; Springer, Stanne \& Donovan, 1999; The Swedish National Agency for Education, 2009; Säljö et al., 2011). The presumption of whether or not students can learn both subject knowledge and collaborative abilities when working as a group represents the most significant potential barrier or enabler to the wider use of group work (Hammar Chiriac \& Forslund Frykedal, 2011). If teachers presume that students merely learn collaboration abilities and not subject knowledge, and are consequently reluctant if not wholly unwilling to use group work, it could be one additional explanation as to why group work has decreased as a pedagogical mode. If this is the case, students will be deprived of the benefits generated by group work as a pedagogical mode, such as learning to inquire, share ideas, clarify differences and construct new understandings (Webb \& Mastergeorge, 2003).

One limitation of this study is that we draw upon a limited number of focus groups, with the constituent information largely consisting of teachers' self-reported statements. Other 
methods of data collection could have contributed additional information or alternative perspectives. Classroom observation would have been an appropriate complementary method, although we found the focus groups to be an acceptable method given the research questions of interest to this paper. In an attempt to assess the accuracy of this study we have tried to ensure consistency between research question, data collection and analysis - that is, an internal logic (Bryman, 2012; Larsson, 2005). A high degree of correlation between research results and the theoretical ideas elicited by the study is also a significant argument in favour of the presence of an internal logic.

\section{Conclusions}

The results clearly demonstrate that teachers' managing roles, based on leadership and teachership as well as presumptions, influence teachers' willingness to use group work as a pedagogical mode. These presumptions may increase or decrease the likelihood of teachers selecting group work. A core finding of this study is that teachers' presumptions provide significant supplementary information explaining why group work has become less common in classrooms. The most significant presumption concerns the possibility of learning both subject knowledge and collaborative abilities when working as a group. When teachers presume that students learn only collaboration abilities and not subject knowledge, their willingness to use group work as a pedagogical mode will decrease. The results from this study could increase teachers' knowledge and awareness of group work management in the classroom, which in turn could influence their daily practices, abilities and general willingness to use group work as a pedagogical mode, thereby contributing to the ongoing professional development of teachers.

Further research in this area may contribute valuable information and enhanced knowledge for teachers regarding their managing roles when using group work in the classroom, as well as how teachers' presumptions affect their way of managing the pedagogical mode. It could also provide additional explanations for teachers' unwillingness to use group work in the classroom.

\section{References}

American Psychological Association (APA). (2002). Ethical principles of psychologists and code of conduct. Retrieved August 2, 2008, from http://www.apa.org/ethics/code2002.html 
Baines, E., Blatchford, P. \& Chowne, A. (2007). Improving the effectiveness of collaborative group work in primary schools: Effects on science attainment. British Educational Research Journal, 33, 663-680.

Baines, E., Blatchford, P. \& Kutnick, P. (2003). Changes in grouping practices over primary and secondary school. International Journal of Educational Research, 39, 9-34.

Barrett, M. (2007). Practical and ethical issues in planning research. In G. Breakwell, S. M. Hammond, C. Fife-Schaw, \& J. A. Smith (Eds.), Research methods in psychology (pp. 2448). London: Sage Publications.

Bennett, J., Lubben, F., \& Campbell, B. (2004). A systematic review of the use of small-group discussions in science teaching with students age 11-18, and their effects on students' understanding in science or attitude to science: Review summary. York: University of York.

Blumer, H. (1969). Symbolic interactionism: Perspective and method. Berkeley: University of California Press.

British Psychology Society (BPS). (2004). Code of conduct, ethical principles \& guidelines. Retrieved August 2, 2008 from http://don.bps.org.uk/document-download-area/documentdownload\$.cfm?file_uuid=6D0645CC-7E96-C67F-D75E2648E5580115\&ext=pdf

Breakwell, G., Hammond, S. M., Fife-Schaw, C., \& Smith, J. A. (Eds.) (2007). Research methods in psychology. London: Sage Publications.

Bryman, A. (2012). Social research methods. Oxford: Oxford University Press.

Charmaz, K. (2006). Constructing grounded theory: A practical guide through qualitative analysis. London: Sage Publications.

Charon, J. M. (2006). Symbolic interactionism: An introduction, an interpretation, an integration (9th ed.). London: Prentice Hall.

Cohen, E. G. (1994). Restructuring the classroom: Conditions for productive small groups. Review of Educational Research, 64, 1-35.

Ekholm, M. (1996). School climate and educational change: Stability and change in nine Swedish schools. EERA Bulletin, 2.

Galton, M., Hargreaves, L., Comber, C., Wall, D. \& Pell, T. (1999). Changes in patterns of teacher interactions in primary classrooms: 1976-1996. British Educational Research Journal, 25, 23-37.

Gillies, R. M. (2003). Structuring cooperative group work in classrooms. International Journal of Educational Research, 39, 35-49. 
Gillies, R. M. (2008). Teachers' and students' verbal behaviours during cooperative learning. In R. M. Gillies, A. Ashman \& J. Terwel (Eds.), The teacher's role in implementing cooperative learning in the classroom (pp. 238-257). Brisbane: Springer.

Gillies, R. M, Ashman, A., \& Terwel, J. (2008). Concluding remarks. In R. M. Gillies, A. Ashman \& J. Terwel (Eds.), The teacher's role in implementing cooperative learning in the classroom (pp. 258-262). Brisbane: Springer.

Gillies, R. M., \& Boyle, M. (2010). Teachers' reflections on cooperative learning: Issues of implementation. Teaching and Teacher Education, 26, 933-940, doi:10.1016/j.tate.2009.10.034.

Glaser, B. G. (1978). Theoretical sensitivity: Advances in the methodology of grounded theory. Mill Valley, CA: Sociology Press.

Glaser, B. G. \& Strauss, A. L. (1967). The discovery of grounded theory: Strategies for qualitative research. Hawthorne, NY: Aldine de Gruyter.

Granström, K. (1998). Classroom management in Sweden: Swedish classroom rhetoric and practice. In N. Shimahara (Ed.), Politics of classroom life: Classroom management in international perspective (pp. 136-162). New York, NY: Garland Publisher.

Granström, K. (2006). Group phenomena and classroom management in Sweden. In C. M. Evertson \& C. S. Weinstein (Eds.), Handbook of classroom management: Research, practice and contemporary issues. (pp. 1141-1160) Mahwah, NJ: Lawrence Erlbaum Associates.

Granström, K. (2007). Ledarskap i klassrummet [Leadership in the classroom; in Swedish]. In K. Granström, (Ed.), Forskning om lärares arbete i klassrummet [Research into teachers' work in the classroom; in Swedish] (pp.13-32). Stockholm: Myndigheten för skolutveckling [The authority for school development].

Hammar Chiriac, E. (2010). Research on group work in education. NY: Nova Science Publishers, Inc.

Hammar Chiriac, E. \& Forslund Frykedal, K. (2011). Management of group work as classroom activity. World Journal of Education, 1, 3-16. doi:10.5430/wje.v1n2p3

Hammar Chiriac, E. \& Granström, K. (2009). Prerequisites for meaningful group workStudents' experiences of co-operation. In S. Jern \& J. Näslund (Eds.), Dynamics within and outside the lab: Proceedings from the 6th Nordic Conference on Group and Social Psychology, Lund University, May, 2008. Linköping: Linköping University.

Hammar Chiriac, E. \& Granström, K. (2012). Teachers' leadership and students' experience of group work. Teachers and Teaching: Theory and Practice, 18, 345-363. 
Johnson, D. W. \& Johnson, F. P. (2003). Joining together: Group theory and group skills. Boston, MA: Allyn and Bacon.

Johnson, D. W. \& Johnson, R. T. (2004). Assessing students in groups: Promoting group responsibility and individual accountability. Thousand Oaks, CA: Corwin Press.

Larsson, S. (2005). Om kvalité i kvalitativ forskning [On quality in qualitative reserach]. Nordisk pedagogik, 25, 16-35.

Lotan, R. A. (2006). Managing group work in the heterogeneous classroom. In C. M. Evertson \& C. S. Weinstein (Eds.), Handbook of classroom management: Research, practice, and contemporary issues (pp. 525-540). Mahwah, NJ: Lawrence Erlbaum Associates.

Lotan, R. A. (2008). Developing language and mastering content in heterogeneous classrooms. In R. M. Gillies, A. Ashman, \& J. Terwel (Eds.), The teacher's role in implementing cooperative learning in the classroom (pp. 184-200). Brisbane: Springer.

Lumpe, A. T., \& Haney, J. J. (1998). Science teacher beliefs and intentions regarding the use of cooperative learning. School Science and Mathematics, 98, 123-135.

Millward, L. J. (2007). Focus groups. In G. Breakwell, S. M. Hammond, C. Fife-Schaw \& J. A Smith (Eds.), Research methods in psychology (pp. 274-292). London: Sage Publications.

Oliveira, A. W. \& Sadler, T. (2008). Interactive patterns and conceptual convergence during student collaborations in science. Journal of Research in Science Teaching, 45, 634-658.

Sanford, J. P. \& Evertson, C. M. (1982). Time use and activities in junior high classes. Journal of Educational Research, 63, 143-147.

Schmuck, R. A. \& Schmuck, P. (1992). Group processes in the classroom. Dubuque: William C. Brown.

The Swedish National Agency for Education (2009). Vad påverkar resultaten i svensk grundskola? Kunskapsöversikt om betydelsen av olika faktorer. Sammanfattande analys. [What affects the results of the compulsory school? Knowledge review about the role of various factors. Summary analysis; in Swedish.] Stockholm: The Swedish National Agency for Education.

Springer, L., Stanne, M. E. \& Donovan, S. S. (1999). Effects of small-group learning on undergraduates in science, mathematics, engineering and technology: A meta-analysis. Review of Educational Research, 69, 21-51.

Säljö, R., Jakobsson, A., Lilja, P., Mäkitalo, Å. \& Åberg, M. (2011). Att förädla information till kunskap. Lärande och klassrumsarbete i mediesamhället. [Refining information into 
knowledge: Learning and classroom work in the media society; in Swedish]. Stockholm: Nordstedts.

Summers, J. J., Beretvas, S. N., Svinicki, M. D. \& Gorin, J. S. (2005). Evaluating collaborative learning and community. Journal of Experimental Education, 73, 165-188.

Webb, N. M. (2008). Teacher practices and small-group dynamics in cooperative learning classrooms. In R. M. Gillies, A. Ashman \& J. Terwel (Eds.), The teacher's role in implementing cooperative learning in the classroom (pp. 201-221). Brisbane: Springer.

Webb, N. M. \& Mastergeorge, A. (2003). Promoting effective helping behavior in peerdirected groups. International Journal of Educational Research, 39, 73-97.

Webb, N. M., Nemer, K. M., \& Ing, M. (2006). Small-group reflections: Parallels between teacher discourse and student behavior in peer-directed groups. Journal of the Learning Sciences, 15, 63-119.

Williams, P., \& Sheridan, S. (2010). Conditions for collaborative learning and constructive competition in school. Educational Research, 52, 335-350. 